the industry may be considered a variety. One type of tortoise core now described for the first time appears peculiar to the Clactonian of Swanscombe, while another approximates to those characteristic of Crayford. Some of the cores are remarkable for their size and weight, two described weighing $16 \mathrm{lb}$. and $19 \mathrm{lb}$. respectively. Ten types of artefacts are distinguished and the series dealt with in the present paper, and in that published in 1929, illustrate all the types of Clactonian implements so far known at Swanscombe.

A communication from Miss N. F. Layard described the discovery in the Buttermarket, Ipswich, of bone implements beneath $9 \mathrm{ft}$. of soft gravel, and at a depth of $23 \mathrm{ft}$. from the surface. A bone needle with hour-glass perforation, a bone awl, the handle of some implement, and an antler tine perforated for suspension, were associated with a human tooth and fragment of jawbone. The objects were removed from the matrix by Miss Layard, personally, in 1899 , and the circumstances carefully noted at the time. It was submitted that the needle corresponded with the broken-eyed needles found by M. Didon in the Abri Blanchard, Dordogne, in an Aurignacian deposit and other late palæolithic cave deposits in France, figured by Didon and by Lartet. Mr. J. Reid Moir stated that, if actually in situ in the deposit described, the specimens would be of Palæolithic age. $\mathrm{Mr}$. M. C. Burkitt compared the finds with those made at the Wookey Hole, which were of Late Celtic age, and doubted their greater antiquity.

Lieut. K. R. U. Todd exhibited flint implements discovered in the alluvial beds bordering the south shore of the Orwell Estuary and submerged at high tide. One industry is characterised by long blades associated with burins ; one was $137 \mathrm{~mm}$. in length, while a hundred measured specimens gave an average length of $67 \mathrm{~mm}$. Dr. Godwin's analysis of the peat on which certain implements of early Neolithic forms rested indicated a temperate climate of post-glacial, Atlantic type, whereas the similar long blade industry found on the north shore of the estuary and described by Mr. J. Reid Moir, had been tentatively referred to the Madelenian by Prof. H. Breuil, and the measurements of the present specimens from the south bank were very near those from the type station of La Madeleine. Mr. M. C. Burkitt and Mr. Graham Clark compared the industry associated with the floor in the peat with that at Lower Halstow, and emphasised the occurrence of burins in Mesolithic times. It has to be remarked, however, that there is more than one cultural horizon in the Orwell alluvial beds, and that it is now regarded as highly probable that the long-blade industry comes from floors at lower levels than those yielding the flints for which Mesolithic associations were claimed in the discussion.

\section{Experimental Gob Fires}

$\mathrm{T}$ HE Safety in Mines Research Board has issued papers Nos. 75 and 76 , concerning gob fires, written by T. N. Mason and F. V. Tideswell (London : H.M. Stationery Office, 1933. 1s. net and $6 d$. net). The first of these deals with the possibility of explosions in sealed-off areas in non-gassy seams, and the second with the possibility of the revival of heating by in-leakage of air. The experiments were carried out in a special building arranged for the purpose at the Experimental Station at Buxton. This building consists of a central chamber $30 \mathrm{ft}$. square and $9 \mathrm{ft}$. high to simulate a mine goaf, circumscribed by an air-course approximately $6 \mathrm{ft}$. wide by $7 \mathrm{ft}$. high. The chamber and air-course are connected by doors $6 \mathrm{ft}$. square capable of being closed, and in one corner of the air-course there is a centrifugal blowing fan.

The first group of experiments simulated a fire in the goaf in a pack situated centrally in the goaf chamber ; with an open fire it was found that there was no possibility of the formation of an inflammable atmosphere; with an enclosed fire this was found to be possible, though no inflammable atmospheres were actually produced under the conditions of the experiments. The next set of experiments simulated a gob fire developed in a roadside coal pack such as would be caused by a partly crushed pillar with a waste area behind. The most dangerous condition was when the fire was supplied with air from a leakage from intake to return, which also partly ventilated the waste.

A third set of experiments simulated fires in dirt packs adjoining a waste, the dirt containing as usual in practice approximately ten per cent of coal. Apparently no explosions occurred, but it is not safe to conclude that such conditions would never lead to the formation of an inflammable atmosphere. Special emphasis is laid on the fact that if an underground fire is to be sealed-off, the sooner and the more quickly that operation is carried out the better. The maximum danger of the formation of an explosive mixture is immediately after the sealingoff.

Paper No. 76 shows that an in-leakage of air which causes the oxygen content to rise to as little as 5 per cent (in one case 3 per cent only) usually results in a marked increase in activity of the heating. It was found that when the temperature had fallen so low as $75^{\circ} \mathrm{C}$, a fire may be revived under suitable conditions. It is pointed out that although the flame of a safety lamp is extinguished when the oxygen in the air has fallen below 17 per cent, that is no guide whatever in determining whether an atmosphere is capable of extinguishing a gob fire or not.

\section{Calendar of Nature Topics}

\section{Second Buchan Cold Spell}

April 11-14.-- Of the six 'cold spells' enumerated by Dr. A. Buchan, the second, April 11-14, receives the least support from either fact or folk-lore. There appears to be no popular saying associating these days with a fall of temperature, and the average daily temperatures at Greenwich from 1841 until 1930 do not reveal any marked cold period in April. An examination of the figures for the individual years at Kew Observatory from 1881 until 1923 showed that April 11-14 had been more often above the temperature to be expected at this season than below it. A different series of years might give a different result, but the inference is clear that Buchan's second cold spell has no real existence in London.

\section{Spawning of Frogs, and a Remarkable Tadpole}

The factors which determine the time of the spawning of frogs, the temperature of the air or the temperature of the water of the spawning pond or 
what not, have not been determined (so far as we recollect), but the range in time of the incidence of spawning suggests that the main factors might be readily discovered. In Hampshire, Gilbert White's earliest record of frogs spawning was February 28, his Iatest March 22; in Sussex, William Marwick's corresponding dates were February 9 and April 10 ; and in Cambridgeshire, Leonard Blomefield found a shorter range, March 4 to March 25, the average of nine years' records being March 16 .

These observations relate to the common frog (Rana temporaria) in England, but in India spawning takes place about the same time, and the discovery of the eggs of Rana afghana in the Khasi Hills towards the end of March 1930, enabled Dr. S. L. Hora to describe the development of the curious suctorial disc by which the tadpole adheres to rock surfaces in the rapid streams in which it lives (Trans. Roy. Soc. Edinburgh, 57, 469 ; 1932). The sucker is formed from the posterior lip of the tadpole, a lunate callous band on the under surface of the body, and lateral folds of skin which at first include the cement organs, although these disappear as the disc becomes functional. Dr. Hora thinks that the origin and development of the sucker can be explained by a series of small and gradual changes induced by recognisable factors in the environment, such as the spoed of the current in which the tadpoles found themselves. The stages in the development of the disc are not necessarily correlated with the size of the specimens, as if the relative swiftness of the stream at different points provided the stimulus for the development of the disc.

\section{Fish Cultivation in the Philippines}

During April and extending to June or July occurs the spawning season of the most important of the sixteen hundred species of fishes recorded from the Philippines--the bañgos or milk-fish (Chanos chanos). It is by far the most common fish in the Manila market, and that because it is the product of a fishpond industry in which a vast amount of capital, estimated at 45 million pesos, has been expended. Somewhat resembling a herring in shape and colour, though far exceeding it in size, this shiny silverywhite fish with pale steel-bluish back owes its value to a combination of qualities. It grows rapidly and may reach a length of three to four and a half feet; it is amongst the most prolific of fishes-a 30 in. female contained a little more than $3,000,000$ eggs, a 44 in. specimen 5,700,000 eggs; it is wholly vegetarian and highly palatable; it is one of the few marine fishes adaptable to artificial cultivation in salt- and brackish-water ponds; and its fry is easily captured in enormous numbers (Adams, Montalban and Martin, Philippine J. Sci., Jan. 1932, p. 1).

The first fish-ponds were tidal and were cut off from the sea except for an opening through which fry could enter but could not return to the sea. That uncertain method of stocking has been replaced in the more advanced fish-ponds by deliberate collection and transference of fry to specially designed ponds. A 10-hectare fish farm should accommodate $25,000-30,000$ fry, at the rate of 50 fish to a square metre of pond; from these about $15,000-18,000$ will reach the fingerling stage, which is transferred to growth ponds; and the final harvest may be reckoned at 9,000-11,000, or 900-1,100 per hectare. Although the bangos reach quite a large size in the ponds, they never become mature, and breed only in the open sea.

\section{Societies and Academies}

\section{LONDON}

Physical Society, Feb. 3. F. J. W. Whipple: Relations between the combination coefficients of atmospheric ions. The principal object of the paper is to put forward for consideration a formula, $\eta_{12}-\eta_{10}=4 \pi e w_{1}$, which indicates that the combination coefficient $\eta_{12}$ for small ions and large ions of the opposite sign exceeds the coefficient $\eta_{10}$ for small ions and uncharged nuclei, and further that the difference between the two coefficients depends on the mobility $w_{1}$ of the small ions. The experimental evidence for the formula is discussed as well as possible applications. G. P. Thomson, Norman Stuart and C. A. Murison: The crystalline state of thin spluttered films of platinum. Films of platinum spluttered in various gases have been examined by the method of electron diffraction. They often show patterns which indicate that the small crystals are oriented with one face parallel to the surface of the specimen, the crystals being otherwise at random and in many cases the crystals are very small, of the order $5 \times 10^{-7} \mathrm{~cm}$. Some films of platinum dioxide showed crystals of the order $2 \times 10^{-7} \mathrm{~cm}$. E. V. ApPleton and R. NAISMith : Weekly measurements of upper atmospheric ionisation. The ionisation is $2 \cdot 2$ times as intense on a summer noon as on a winter noon, and, in general, was slightly less in 1932 than in 1931. This reduction is due to the approach of sunspot minimum, and, with other evidence, suggests that the ionising agency from the sun varies by as much as 60 per cent during the 11-year solar period. Although ultra-violet light is accepted as the major ionising agency, thunderstorms most probably constitute one of the subsidiary causes, as previously suggested by C. T. R. Wilson. J. A. Ratchiffe and E. L. C. White: An automatic recording method for wireless investigations of the ionosphere. The Breit and Tuve method is employed, and both the transmitter and the time base at the receiver are synchronised with the A.C. mains. Some specimen records are reproduced and are used to illustrate the normal diurnal variation of equivalent height. Attention is directed to a common 'abnormal' occurrence of increase of ionisation in the lower $(E)$ region, during the hours of darkness, without a corresponding increase in the upper $\left(F^{\prime}\right)$ region, due possibly to storm clouds, as suggested by C. T. R. Wilson.

\section{EDINBURGH}

Royal Society, March 6. J. B. Simpson : The lateglacial re-advance moraines of the Highland border west of the River Tay. Following upon the westward retreat of the last general ice-sheet from the central valley of Scotland and an incursion of the sea when the land level was at least $90 \mathrm{ft}$. lower than now, considerable re-advances of the ice occurred on at least two occasions. The first of these is described in detail for the district between Dumblane and Perth. From varved clays the period between the retreat and the re-advance is estimated at 640 years. This re-advance is correlated with the $\mathrm{Ra}$ moraines of Scandinavia. A later re-advance is marked by striking terminal moraines in the Upper Forth Valley and Loch Lomond areas. E. B. BAILEY : Help from America in reading Scottish tectonics. It is now 